\title{
Streptococcus pneumoniae and Mycoplasma pneumoniae coinfection in community acquired pneumonia
}

\author{
P Toikka, T Juvén, R Virkki, M Leinonen, J Mertsola, O Ruuskanen
}

\begin{abstract}
The characteristics of nine children with community acquired pneumonia with evidence of Streptococcus pneumoniae and Mycoplasma pneumoniae coinfection are described.

(Arch Dis Child 2000;83:413-414)
\end{abstract}

Keywords: Streptococcus pneumoniae; Mycoplasma pneumoniae; pneumonia; coinfection

Mixed viral-bacterial infections as well as viral-viral infections are not uncommon in childhood pneumonia, and dual bacterial infections have also been described. ${ }^{1}$ We describe the clinical characteristics and outcome of nine children with community acquired pneumonia with serological evidence of both Streptococcus pneumoniae and Mycoplasma pneumoniae infections.

Department of Pediatrics, Turku University Hospital,

Vähä Hämeenkatu $1 \mathrm{~A}$

3, FIN-20500 Turku,

Finland

P Toikka

T Juvén

J Mertsola

O Ruuskanen

Department of Radiology, Turku University Hospital R Virkki

National Public Health Institute, Oulu, Finland

M Leinonen

Correspondence to: Dr Toikka

pia.toikka@utu.fi

Accepted 20 July 2000

Table 1 Tests positive for Mycoplasma pneumoniae and Streptococcus pneumoniae in children with coinfection

\section{Patients and methods}

Between 1 January 1993 and 31 December 1995, the aetiology of community acquired pneumonia was studied in 254 hospitalised children at the Department of Paediatrics, Turku University Hospital. ${ }^{2}$ The bacteria implicated were $S$ pneumoniae, $M$ pneumoniae, Moraxella catarrhalis, Haemophilus influenzae, Streptococcus pyogenes, and Chlamydia pneumoniae. The viruses implicated were respiratory syncytial virus, rhinovirus, parainfluenza virus types 1,2 , and 3 , adenovirus, human herpesvirus 6 , influenza $\mathrm{A}$ and $\mathrm{B}$ virus, and coronavirus. Informed consent was obtained from the parents or guardians of children serving as study subjects.

$M$ pneumoniae infection was identified by studying IgM and IgG antibodies in acute and convalescent phase serum samples and/or positive nasopharyngeal aspirate culture. ${ }^{2}$ In

\begin{tabular}{|c|c|c|}
\hline $\begin{array}{l}\text { Case } \\
\text { no. }\end{array}$ & Tests positive for Mycoplasma pneumoniae & $\begin{array}{l}\text { Tests positive for Streptococcus } \\
\text { pneumoniae }\end{array}$ \\
\hline 1 & $\operatorname{IgM}(2,27)^{\star}, \mathrm{CA}(2)$ & Pneumolysin IC \\
\hline 2 & IgM (33), IgG (riset), culture (1), CA (1) & Pneumolysin IC \\
\hline 3 & IgM (27), IgG (rise), culture (1) & Pneumolysin IC \\
\hline 4 & $\operatorname{IgM}(1,30), \operatorname{IgG}($ rise $), \mathrm{CA}(1)$ & Pneumolysin IC \\
\hline 5 & $\operatorname{IgM}(1,24), \operatorname{IgG}$ (rise) & $\begin{array}{l}\text { Pneumolysin IC, pneumolysin } \\
\text { IgG, C polysaccharide IgG }\end{array}$ \\
\hline 6 & $\operatorname{IgM}(1), \operatorname{IgG}(1)$ & Pneumolysin IC \\
\hline 7 & $\operatorname{IgM}(1,29)$ & $\mathrm{C}$ polysaccharide $\mathrm{IgG}$ \\
\hline 8 & $\operatorname{IgM}(1,26)$ & Pneumolysin IgG \\
\hline 9 & $\mathrm{CF}$ (rise) & $\begin{array}{l}\text { Pneumolysin IC, pneumolysin } \\
\text { IgG, C polysaccharide IgG }\end{array}$ \\
\hline
\end{tabular}

${ }^{\star}$ Days at which positive tests for $M$ pneumoniae were obtained after admission. †Twofold or greater rise in antibody titres between paired samples.

IC, immune complexes; CA, cold haemagglutinins; $\mathrm{CF}$, complement fixation test.

some cases, the complement fixation (CF) test and/or cold haemagglutinin tests were carried out according to standard methods. For detection of $S$ pneumoniae infection, pneumolysin IgG antibodies and pneumolysin immune complexes as well as $\mathrm{C}$ polysaccharide $\mathrm{IgG}$ antibodies and immune complexes were measured in acute phase and convalescent phase serum samples. ${ }^{2}$ Blood cultures were obtained from two patients. The methods have been described previously. ${ }^{2}$

\section{Results}

Pneumonia caused by $M$ pneumoniae was diagnosed in 17 patients, and pneumonia caused by $S$ pneumoniae in 93 patients. Of these, evidence of coinfection of $M$ pneumoniae and $S$ pneumoniae was found in nine patients (table 1). Three of the nine children with coinfection also had evidence of viral infection (rhinovirus, influenza A virus, and human herpes virus 6 ). In addition, one child had evidence of $H$ influenzae infection and one had evidence of $M$ catarrhalis infection as a third possible causative agent. All nine patients were febrile before admission $\left(>37.5^{\circ} \mathrm{C}\right)$. Seven patients had symptoms of respiratory tract infection. Five patients appeared ill. One patient had otitis media and one had maxillary sinusitis as well as tonsillitis. All patients had alveolar infiltrations in their chest radiographs: four solely and five with interstitial infiltrations. Five children had a $\mathrm{C}$ reactive protein concentration greater than $80 \mathrm{mg} / 1$ or a white blood cell count greater than $15 \times 10^{9} / 1$. In the hospital, seven patients were initially treated with $\beta$ lactam antibiotics (table 2 ), and two patients received macrolide treatment. Finally, five of the nine patients received macrolide treatment either before hospitalisation, in the hospital, or after discharge. The mean duration of fever $\left(>37.5^{\circ} \mathrm{C}\right)$ after onset of antibiotic therapy was 24.4 (SD 14.5) hours, ranging from 10 to 48 hours in eight patients who were febrile in the hospital. Four of six patients not initially treated with a macrolide had respiratory symptoms or fever for up to seven days after discharge. In two of them, the symptoms disappeared after onset of macrolide treatment. At the follow up visit three to four weeks after discharge, all patients showed clinical recovery from pneumonia, but four (of the eight) patients still had minor infiltrations on chest radiograph. One patient treated with penicillin and cefadroxil developed otitis media during follow up. 
Table 2 Characteristics of children with Streptococcus pneumoniae and Mycoplasma pneumoniae coinfection

\begin{tabular}{|c|c|c|c|c|}
\hline $\begin{array}{l}\text { Case } \\
\text { no. }\end{array}$ & $\begin{array}{l}\text { Age } \\
(y) / \operatorname{sex}\end{array}$ & $\begin{array}{l}\text { Duration of } \\
\text { symptoms/fever } \\
\text { before admission }\end{array}$ & $\begin{array}{l}\text { Treatment in the hospital/after } \\
\text { discharge }\end{array}$ & $\begin{array}{l}\text { Symptoms after } \\
\text { discharge }\end{array}$ \\
\hline 1 & $7.3 / \mathrm{M}$ & $9 \mathrm{~d} / 9 \mathrm{~d}^{\star}$ & Penicillin/cefadroxil & Cough for a week \\
\hline 2 & $10.5 / \mathrm{M}$ & $3 \mathrm{~d} / 3 \mathrm{~d}$ & Erythromycin/erythromycin & None \\
\hline 3 & $1.9 / \mathrm{M}$ & 2 to $3 \mathrm{wk} /<1 \mathrm{~d}$ & Penicillin/penicillin & $\begin{array}{l}\text { Fever, cough, lethargy } \\
\text { for } 5 \text { days }\end{array}$ \\
\hline 4 & $5.3 / \mathrm{F}$ & 2 to $3 \mathrm{wk} /<1 \mathrm{~d}$ & Penicillin/penicillin $\neq$, azithromycin & Fever for 1 day \\
\hline 5 & $2.4 / \mathrm{M}$ & $2 \mathrm{wk} / 2 \mathrm{wk}$ & Penicillin/penicillin $\widehat{\mathbb{S}}$, azithromycin & $\begin{array}{l}\text { Fever and cough for a } \\
\text { week }\end{array}$ \\
\hline 6 & $12.7 / \mathrm{F}$ & $4 \mathrm{wk} / 4 \mathrm{wk} \dagger$ & Azithromycin/azithromycin & None \\
\hline 7 & $1.4 / \mathrm{F}$ & $7 \mathrm{~d} / 4 \mathrm{~d}$ & Penicillin/penicillin & $\begin{array}{l}\text { Rhinitis and cough for } \\
\text { a week }\end{array}$ \\
\hline 8 & $5.6 / \mathrm{F}$ & $7 \mathrm{~d} / 7 \mathrm{~d}$ & Cefuroxime/trimethoprim-sulpha & None \\
\hline 9 & $3.1 / \mathrm{F}$ & $3 d / 3 d$ & Penicillin/penicillin & None \\
\hline
\end{tabular}

* The patient had received a 5-day course of azithromycin before admission. tThe patient had received an 8-day course of cefadroxil before admission. $\neq$ Was changed after one day because of fever.

OOral penicillin treatment was changed to azithromycin after 1 week when a positive test result for M pneumoniae was available.

\section{Discussion}

$S$ pneumoniae and $M$ pneumoniae are the major bacterial causes of community acquired pneumonia in children, together accounting for up to $60 \%$ of cases. ${ }^{1-3}$ In the present study, half of the hospitalised children with $M$ pneumoniae pneumonia had evidence of $S$ pneumoniae coinfection. On the other hand, $10 \%$ of the children with pneumococcal pneumonia had evidence of $M$ pneumoniae infection. Earlier aetiological studies have reported evidence of $S$ pneumoniae and $M$ pneumoniae coinfection in 29 ambulatory or hospital treated children with pneumonia..$^{3-7}$ In a recent study, ${ }^{3}$ patients with the coinfection accounted for $30 \%$ of cases of M pneumoniae infection and for $23 \%$ of cases of pneumococcal infection.

Pneumonia in children may often be caused by multiple microbial agents. ${ }^{1}$ Intercurrent or preceding viral upper respiratory infections are believed to be risk factors for secondary bacterial disease. $M$ pneumoniae infection can also precede viral or other bacterial infections by several days or weeks. ${ }^{8}$ Staugas and Martin ${ }^{9}$ reported five cases of $M$ pneumoniae infection with probable secondary infection from $H$ influenzae. Recently, Cimolai and coworkers ${ }^{8}$ reported four patients with severe bacterial or viral infections either following or coinciding with $M$ pneumoniae respiratory infection. All these studies suggest that $M$ pneumoniae, like respiratory viruses, may predispose to secondary bacterial infection.

In this study, seven patients $(78 \%)$ had been ill for a week or longer before admission, supporting the view that $M$ pneumoniae infection probably precedes $S$ pneumoniae infection. In our earlier study, only $25 \%$ of 85 children with bacteraemic pneumococcal pneumonia had had symptoms for seven or more days at the time of diagnosis. ${ }^{10}$ Patients with $M$ pneumoniae pneumonia are often treated as outpatients. ${ }^{7}$ It is possible that an additional pneumococcal infection, which cannot usually be confirmed by standard laboratory methods, increases symptoms leading to hospitalisation in a patient with $M$ pneumoniae pneumonia.

The study was financially supported by the Maud Kuistila Foundation and the Paulo Foundation.

1 Ruuskanen O, Mertsola J. Childhood community-acquired pneumonia. Semin Respir Infect 1999;14:163-72.

2 Juvén T, Mertsola J, Waris M, et al. Etiology of communityJuvén T, Mertsola J, Waris M, et al. Etiology of community-
acquired pneumonia in 254 hospitalized children. Pediatr Infect Dis $\mathcal{f} 2000 ; 19: 293-8$

3 Heiskanen-Kosma T, Korppi M, Jokinen C, et al. Etiology of childhood pneumonia: serologic results of a prospective, population-based study. Pediatr Infect Dis $\mathcal{F}$ 1998;17:98691

4 Claesson BA, Trollfors B, Brolin I, et al. Etiology of community-acquired pneumonia in children based on antibody responses to bacterial and viral antigens. Pediatr Infect Dis f 1989;8:856-62.

5 Nohynek H, Eskola J, Laine E, et al. The causes of hospitaltreated acute lower respiratory tract infection in children. Am 7 Dis Child 1991;145:618-22.

6 Ruuskanen O, Nohynek H, Ziegler T, et al. Pneumonia in childhood: etiology and response to antimicrobial therapy. Eur F Clin Microbiol Infect Dis 1992;11:1-7.

7 Gendrel D, Raymond J, Moulin F, et al. Etiology and response to antibiotic therapy of community-acquired pneumonia in French children. Eur f Clin Microbiol Infect Dis 1997;16:388-91

8 Cimolai N, Wensley D, Seear M, Thomas ET. Mycoplasma pneumoniae as a cofactor in severe respiratory infections. Clin Infect Dis 1995;21:1182-5.

9 Staugas R, Martin AJ. Secondary bacterial infections in children with proved Mycoplasma pneumoniae. Thorax 1985;40:546-8

10 Toikka P, Virkki R, Mertsola J, Ashorn P, Eskola J, Ruuskanen O. Bacteremic pneumococcal pneumonia in children. Clin Infect Dis 1999;29:568-72. 